\title{
BIODIVERSITY AND BIOACTIVITY OF STROMATIC XYLARIALES COLLECTED FROM MU KO CHANG NATIONAL PARK, THAILAND
}

\author{
SUTJARITVORAKUL, T. ${ }^{1}-$ CHUTIPAIJIT, S. ${ }^{2 *}$ \\ ${ }^{1}$ Faculty of Science and Technology, Pathumwan Institute of Technology, Bangkok 10330, \\ Thailand \\ ${ }^{2}$ College of Nanotechnology, King Mongkut's Institute of Technology Ladkrabang, Bangkok \\ 10520, Thailand \\ *Corresponding author \\ e-mail:thana5306@hotmail.com
}

(Received $13^{\text {th }}$ Aug 2020; accepted $19^{\text {th }}$ Nov 2020)

\begin{abstract}
Ko Chang Island is a tropical rain forest island of $\mathrm{Mu}$ Ko Chang national park, Thailand, which has a wide variety of macro-fungi. The objective of this research was to study the biodiversity of Xylariales and to investigate the bioactive activity of ethyl acetate crude extracts. The fungi were collected from the forest area of the waterfalls all over the island. The crude extracts of selected fungi were tested for antibacterial activity by agar well diffusion method and the cancer cell viability was assessed using the MTT assay. Three genera of Xylariaceae and Hypoxylaceae were found including Xylaria, Daldinia and Hypoxylon. The crude extracts inhibited the growth of Gram positive bacteria more than that of Gram negative bacteria and showed broad spectrum inhibition to all cancer cell lines. The crude extract of Xylaria sp.3 showed the highest potential of antibacterial activity and selectively inhibited gastric carcinoma (Kato III) and $\mathrm{T}$ cell leukemia (Jurket) with the percentage survival of $26.12 \pm 0.90 \%$ and $35.37 \pm 0.40 \%$ respectively. The molecular identification of Xylaria sp.3 was identified as Xylaria sp.TP5BS101. These results show that these macromycetes are an excellent repertoire of antibacterial activity and exhibit anticancer activity against Kato III and Jurket by inducing DNA fragmentation.
\end{abstract}

Keywords: Xylariaceous fungi, diversity, antibacterial activity, anticancer activity

\section{Introduction}

The Xylariaceae and Hypoxylaceae include some of the most diverse and interesting fungi in the Xylariales order. Xylaria is the largest genus in the family Xylariaceae, covering about forty genera. These are mainly wood-decaying fungi, but some species are classified as plant pathogenic fungi (Whalley, 1996; Edwards et al., 2003). This family is widely distributed in tropical and temperate climate regions, and can be found on many substrates such as dead wood, leaf litter, dung and soil (Ramesh et al., 2012; Velmurugan et al., 2013). The teleomorph stages of the Xylariaceae and Hypoxylaceae are often formed on stromata such as Xylaria, Daldinia, Rosellinia and Hypoxylon (Orachaipunlap et al., 2016). Moreover, they are also known as fungal endophytes that live inside healthy plant tissue for at least part of their life cycle without causing any disease symptoms in the host plants (Petrini and Petrini, 1985). The endophytic Xylariaceae are especially common endophytes in many tropical plants including Dipterocarpus plants, Mangrove plants, palms, ferns and orchids (Rodrigues, 1994; Fróhlicha et al., 2000; Sutjaritvorakul et al., 2011). They can produce many kinds of bioactive secondary metabolites with great potential for biotechnological applications such as antimicrobial, anticancer, antioxidant, antiviral, nematicidal and anti-inflammatory activity (Osmanova et al., 2010; 
Orachaipunlap et al., 2016; Helaly et al., 2018). Fungal endophytes have been discovered to be latent pathogens or decomposers, waiting for host plant weakness or death to colonize and decompose plant tissue. Therefore, the biodiversity of wood-decaying Xylariaceae should be spatially coupled with the distributions of those woody plants (Edwards et al., 2003; Thomas et al., 2016).

Ko Chang Island is a major island of $\mathrm{Mu}$ Ko Chang national park, Trat province, eastern Thailand $\left(12^{\circ} 6^{\prime} 13^{\prime \prime} \mathrm{N} \& 102^{\circ} 21^{\prime} 7^{\prime}\right.$ 'E). Unlike other provinces in the East, Trat province is located in the eastern tip of the east of Thailand and has a tropical monsoon climate. Ko Chang Island is characterized by an average temperature of $27^{\circ} \mathrm{C}$. In the rainy season the maximum rainfall averages $4700 \mathrm{~mm}$ in May - October. This island is far from the river streams of the mainland, and the sea water around the island. In addition, Ko Chang Island has many waterfalls with a wide variety of woody plants because this island is one of only a few islands where a tropical rainforest is distributed over $70 \%$ of the inland area (Pumijumnong and Payomrat, 2013). However, there has been no report on the biodiversity of Xylariales in Ko Chang Island. This report is therefore the first report on biodiversity and their bioactivity of fungi in this family. Thus, the ultimate goal of this research was to investigate the biodiversity of saprophytic Xylariales collected from the forest area of waterfalls around Ko Chang Island and to investigate the bioactive activity of ethyl acetate crud extractsagainst both Gram negative and Gram positive human pathogenic bacteria and human cancer cell lines.

\section{Materials and methods}

\section{Sampling site}

Stromata of Xylariaceae and Hypoxylaceae were collected from the forest area of the waterfalls all over the island including Klong Plu waterfall (west coast), Klong Jao Leuam waterfall (northwest coast), Than Mayom waterfall (east coast) and Kheeri Petch waterfall (southeast coast) (Figure 1). This research was performed in June 2018.

\section{Isolation and identification}

Fresh stromata of Xylariaceae and Hypoxylaceae were identified and authenticated on the basis of macro- and microscopic characteristics according to Ju and Rogers (1996) and Koyani et al. (2016). The pure cultures were isolated from ascospores under light microscopy by single-spore isolation technique (Velmurugan et al., 2013) and were cultivated on potato dextrose agar (PDA) to obtain pure cultures. Molecular identification of the selected fungi was undertaken following inoculation of pure culture disks into 100 $\mathrm{ml}$ of potato dextrose broth (PDB) and incubated at $25^{\circ} \mathrm{C}$ for 7 days. The mycelial biomass was harvested and extracted by using the CTAB method (cetyltrimethyl ammonium bromide) to obtained fungal DNA following the standard protocols used in Elias et al. (2018). The polymerase chain reaction (PCR) used the primers which are ITS1F (5'-TCCGTAGGTGAACCTGCGG-3') and ITS4 (5'TCCTCCGCTTATTGATATGC-3'), and PCR amplifications were performed by following the condition of Sutjaritvorakul et al. (2016). The homology studies of the fungal DNA sequences obtained were compared with the sequences of known species in the NCBI's GenBank database. 


\section{Diversity analysis}

The value of diversity analysis was expressed in Simpson's diversity index (D). It was determined according to the following equation (Simpson, 1949).

$$
D=1-\left(\frac{\sum(n i-1)}{N(N-1)}\right)
$$

$\mathrm{ni}=$ Total number of organisms of a particular species

$\mathrm{N}=$ Total number of organisms of all species

$\mathrm{D}=$ Simpson's diversity index

\section{Fungal cultivation for biological assay}

Disks of cultured fungi were cut from the edge of an actively growing colony on PDA with a flamed cork borer $(6 \mathrm{~mm})$ and transferred into 500 Erlenmeyer flasks containing of malt extract broth (MEB) $(200 \mathrm{ml})$. All cultures were incubated for one month at room temperature $\left(25^{\circ} \mathrm{C}\right)$ under static conditions. After the incubation period the mycelium was separated by filtration and the cultured filtrate was extracted with $300 \mathrm{ml}$ of ethyl acetate. Each extracted solution was evaporated in a rotary vacuum evaporator at $40^{\circ} \mathrm{C}$ (BUCHI, $\mathrm{V}-800$ ). The ethyl acetate crude extracts were dissolved in dimethylsulphoxide (DMSO), filtered through a syringe filter $0.22 \mu \mathrm{m}$ and stored at $4^{\circ} \mathrm{C}$ as stock solution for bioassays (Orachaipunlap et al., 2016).

\section{Screening for antibacterial activity}

In this research, human pathogenic bacteria, including two Gram-positive bacteria, Staphylococcus aureus ATCC 25623, Bacillus cereus ATCC 6633 and two Gramnegative bacteria, Pseudomonas aeruginosa ATCC 27853, Escherichia coli ATCC 8739 were tested for antibacterial activity by agar well diffusion method. The tested bacteria were normalized to the solution turbidity of $0.5 \mathrm{McFarland}$ standard solutions and were spread on mueller-hinton agar (MHA). The wells of $4 \mathrm{~mm}$ diameter were punch with sterile capillary glass and $100 \mu \mathrm{l}$ of each sample was added to the agar well (Sutjaritvorakul and Chutipaijit, 2018). The plates were incubated at $37{ }^{\circ} \mathrm{C}$ for $24 \mathrm{~h}$. The magnitude of antimicrobial activity was assessed by the diameter of halo inhibition zone relative to those of the positive control (Streptomycin).

\section{Evaluation of anticancer activity}

The effect of ethyl acetate crude extract on cell viability was assessed using the 3-(4,5dimethylthiazol-2-yl)-2,5-diphenyltetrasodium bromide assay (MTT) against 4 human cancer cell lines including gastric carcinoma (Kato III) (ATCC no HTB-103), liver hepatoblastoma (HepG2) (ATCC no HB-8065), colorectal adenocarcinoma (SW620) (ATCC no CCL-227) and acute T cell leukemia (Jurket) (ATCC no CRL-2063). These cell lines were obtained from Department of Microbiology, Faculty of Science Chulalongkorn University, Thailand. Cell suspensions in RPMI 1640 medium were pipetted into flat-bottomed 96 well plats at density of $1 \times 10^{5}$ cells/well and incubated at $37^{\circ} \mathrm{C}$ in a $5 \% \mathrm{CO}_{2}$ atmosphere for $24 \mathrm{~h}$. As much as $50 \mu \mathrm{l}$ of the ethyl acetate crude extract was added to wells and incubated under the same conditions. MTT solution was added to each well and incubated under the same conditions for $4 \mathrm{~h}$. The formazan salt was 
dissolved by $150 \mu \mathrm{l}$ of DMSO and the absorbance at $540 \mathrm{~nm}$ was measured using a microplate reader. The percentage of cell viability was calculated using following formula (Rezk et al., 2015).

$$
\text { Percentage of cell viability }=\left(\frac{\text { Absorbance of treated cells }}{\text { Absorbance of control cells }}\right) \times 100
$$

\section{Investigation of DNA fragmentation}

The extracts of selected fungi were tested for inducible apoptotic cell death detected by staining of DNA with Hoechst 33342 fluorescence dye. The cell lines suspension at $1 \times 10^{6}$ cells $/ \mathrm{ml}$ of cancer cell were plated on the coverslip in Petri dishes and incubated at $37^{\circ} \mathrm{C}$, with $5 \% \mathrm{CO}_{2}$ and at $95 \%$ relative humidity for $24 \mathrm{~h}$. After that, the cancer cells were treated with $50 \mu 1$ of ethyl acetate crude extract. DMSO and etoposide $(10 \mu \mathrm{M})$ were used as negative and positive control respectively. The medium was removed and washed with phosphate buffered saline (PBS) at pH 7.4. The nucleus of cancer cells were stained with Hoechst 33258 fluorescence dye $(1 \mu \mathrm{g} / \mathrm{ml}$ in PBS $)$ and covered with a glass slide. Finally, cell apoptosis was observed under fluorescence microscopy (Olympus, IX71) (Pharamat et al., 2013).

\section{Statistical analysis}

The data represent mean of three replicates. Results were subjected to Completely Randomized Design (CRD) and analyaed by one-way analysis of variance (ANOVA). The mean comparisons were performed by Dancan's Multiple Range Test (DMRT) at a a significant level of $P \leq 0.05$. Statistical analyses were conducted using SPSS (SPSS for Windows version 15, SPSS Inc., Chicago, USA).
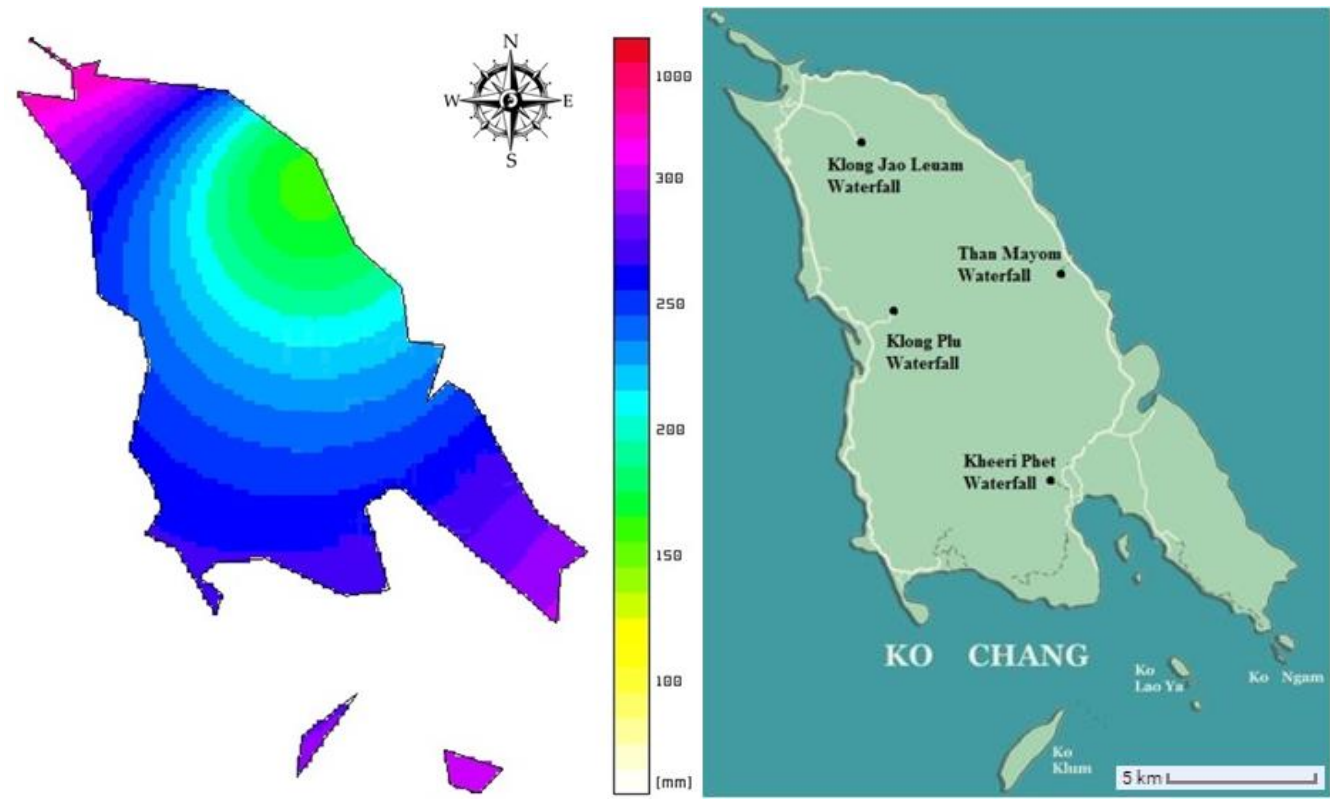

Figure 1. The average rainfall of Ko Chang Island, Mu Ko Chang National Park, Trat Province in June 2018, Study site (•) 


\section{Results}

The average rainfall of surveyed period $(261.5 \mathrm{~mm}$.) and study sites are shown in Figure 1 (Data obtained from Hydro and Agro Informatics Institute, Ministry of Science and Technology, Thailand). Three genera and eleven species of Xylariaceae were found in the vicinity of four waterfalls around Ko Chang Island, Trat province (Table 1). Figure 2 exhibits different morphotypes of xylariaceous fungi collected from Ko Chang Island. Xylaria sp.5 can be found at every waterfall site while Xylaria sp.1, Xylaria sp.4 and Xylaria sp. 8 can be found only by Klong Plu waterfall. They were mostly found on dead wood, except Xylaria sp.3 and Xylaria sp.4 which were found on leaves and soil respectively. Moreover, Daldinia concentrica can be found near Klong Plu, Klong Jao Leuam and Than Mayom waterfalls. Two species belonging to the genus Hypoxylon, could not be identified at the species level by morphological characters. The diversity index of Xylariales was presented in Table 1. The Simpson's diversity index (D) ranges between 0 and 1 (Eq.1). With this index, 1 represents infinite diversity and 0 represents no diversity. The Klong Jao Leuam waterfall showed the highest Simpson's diversity index (0.80), while Than Mayom showed the lowest diversity index (0.55) compared with the other waterfall.

Table 1. The Xylariales collected from Ko Chang Island, Mu Ko Chang National Park

\begin{tabular}{l|c|c|c|c}
\hline \multirow{2}{*}{ Fungal strain } & \multicolumn{4}{c}{ Observed number } \\
\cline { 2 - 5 } & Klong Plu & Kheeri Phet & Klong Jao Leuam & Than Mayom \\
\hline Xylaria sp.1 & 5 & - & - & - \\
Xylaria sp. 2 & 24 & 16 & 26 & - \\
Xylaria sp.3 & - & 36 & 16 & - \\
Xylaria sp.4 & 2 & - & - & - \\
Xylaria sp.5 & 19 & 13 & 18 & - \\
Xylaria sp.6 & - & 7 & - & - \\
Xylaria sp.7 & - & 11 & 21 & - \\
Xylaria sp.8 & 32 & - & - & 2 \\
Daldinia concentrica & 7 & - & 10 & 6 \\
Hypoxylon sp.1 & 2 & - & - & 4 \\
Hypoxylon sp. 2 & - & - & 3 & 0.55 \\
Simpson's diversity index & 0.76 & 0.74 & 0.80 & - \\
\hline
\end{tabular}

The ethyl acetate crude extracts of each fungal isolates were tested for antibacterial activity (Table 2). The results showed that crude extracts of all fungal isolates exhibited antibacterial activity against all tested human pathogenic bacteria. The crude extracts could inhibit the growth of Gram positive bacteria such as $S$. aureus and B. cereus to a greater degree than that of Gram negative bacteria such as $P$. aeruginosa and E. coli. $X y l a r i a$ sp. 3 could inhibit the growth of $S$. aureus and B. cereus with the highest inhibition zone at $20.83 \pm 1.04$ and $15.50 \pm 0.86 \mathrm{~mm}$ respectively.

The anticancer activity test was performed on various cancer cell lines by using MTT method. Table 3 shows the results of anticancer activity of ethyl acetate crude extracts against human cancer cell lines including gastric carcinoma (Kato III), liver hepatoblastoma (HepG2), colorectal adenocarcinoma (SW620) and acute T cell leukemia (Jurket). The ethyl acetate crude extracts of each fungal isolates displayed broad spectrum inhibition to all cancer cell lines. Interestingly, Xylaria sp. 3 specifically inhibited gastric 
carcinoma (Kato III) with the percentage survival of $26.12 \pm 0.90 \%$, and it also inhibited $\mathrm{T}$ cell leukemia (Jurket) with the percentage survival of $35.37 \pm 0.40 \%$. In order to confirm that the cell death is induced by the ethyl acetate crude extract, apoptosis can be observed on Kato III and Jurket when treated with the crude extract of Xylaria sp.3. Figure 3 showed different morphology of Kato III and Jurket cell lines treated with crude extract. The ethyl acetate crude extract of Xylaria sp.3 exhibits potent anticancer activity against both cancer cell lines by inducing DNA fragmentation (arrow). The results indicated that Xylaria sp.3 exhibited considerable biological activity. Therefore, it could produce great potential bioactive secondary metabolites. The molecular identification based on 18S rRNA, comparing results of ITS sequences indicated that Xylaria sp.3 had 99\% homology with Xylaria sp.TP5BS101.

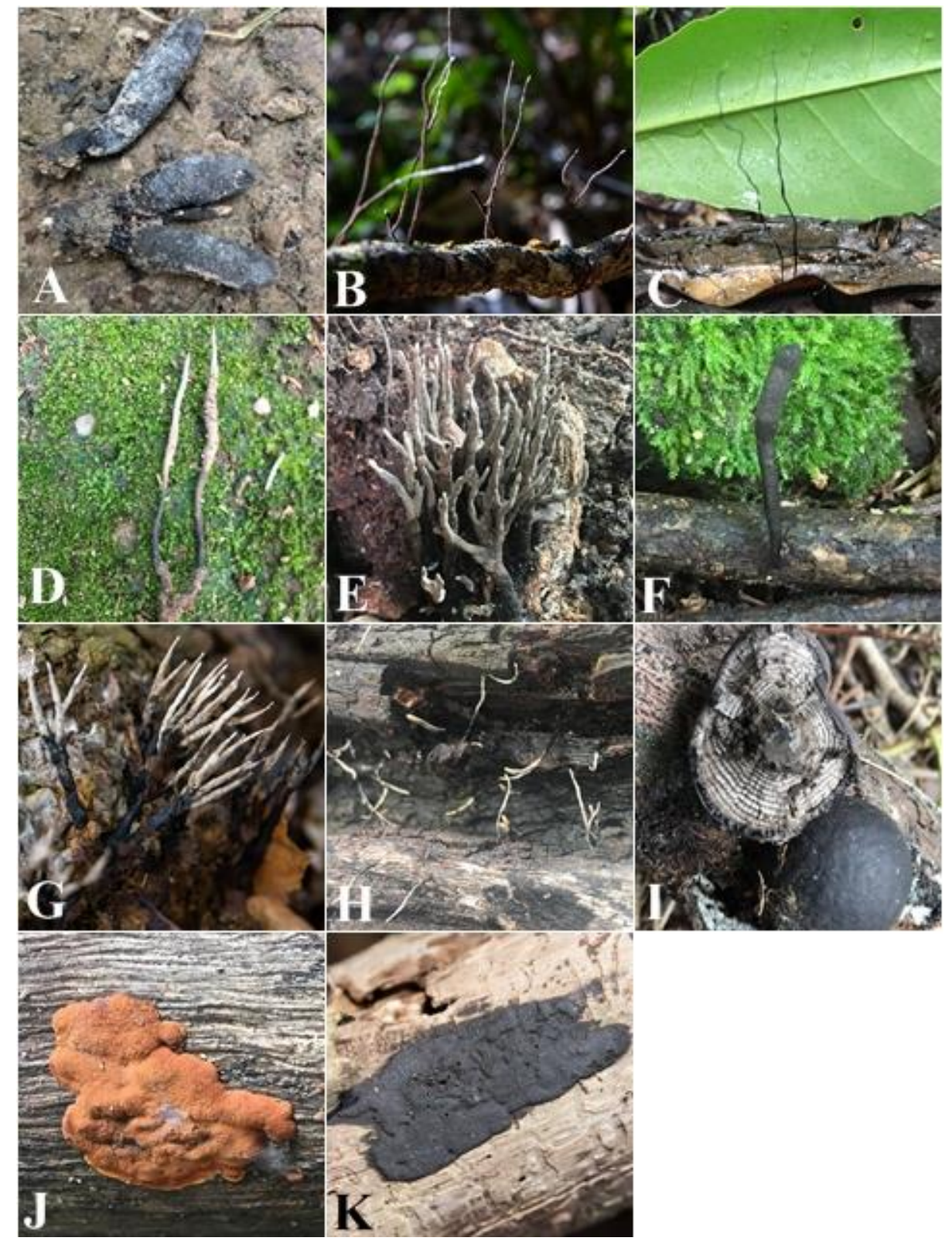

Figure 2. Stromata of the Xylariales collected from Ko Chang Island; Xylaria sp.1(A), Xylaria sp.2(B), Xylaria sp.3 (C), Xylaria sp.4 (D), Xylaria sp.5(E), Xylaria sp.6(F), Xylaria sp.7 $(G)$, Xylaria sp.8 (H), Daldinia concentrica (I), Hypoxylon sp.1 (J), Hypoxylon sp.2(K) 

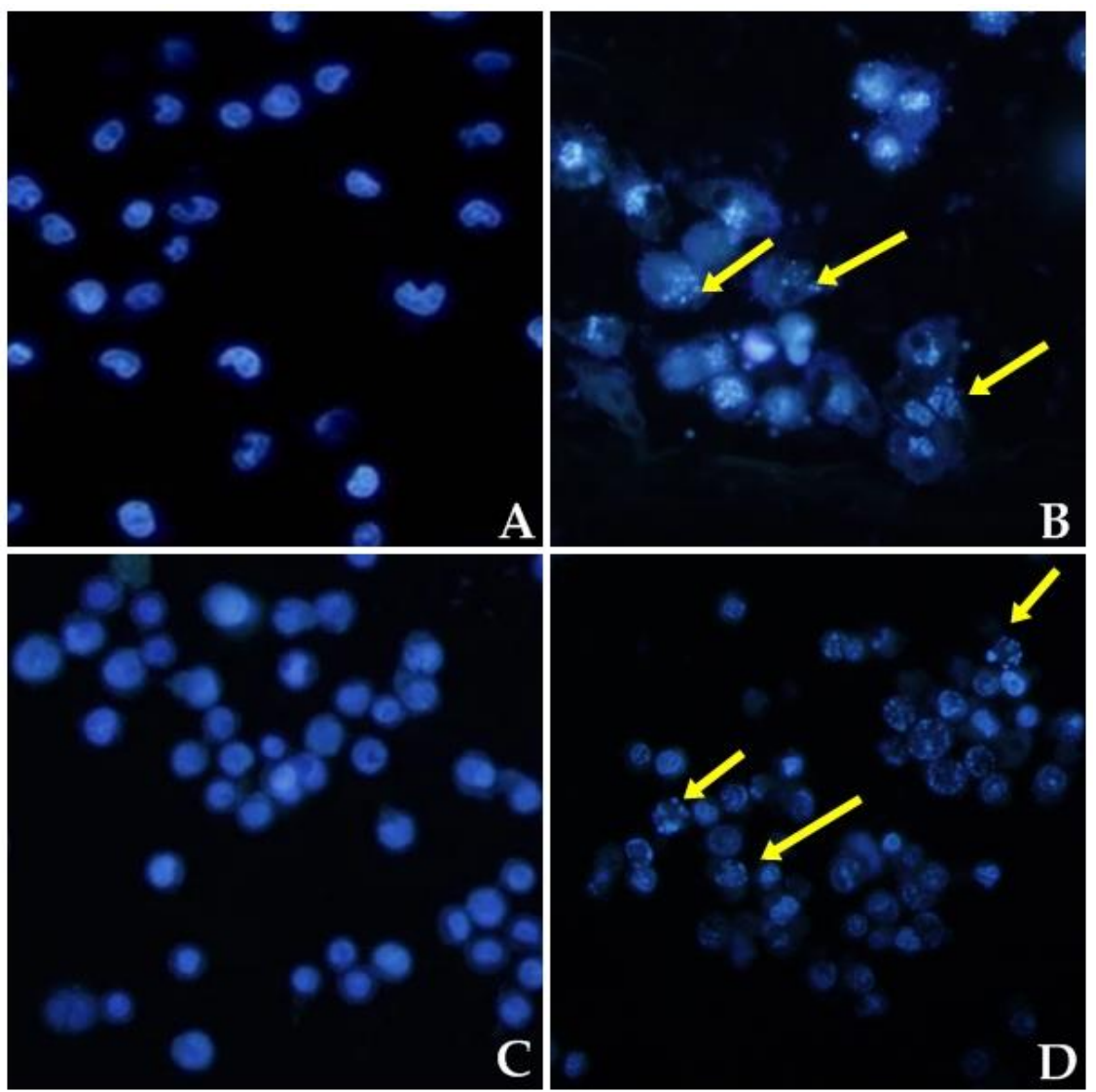

Figure 3. Xylaria sp.3 ethyl acetate crude extracts induced apoptosis in human cancer cell lines for 24 h.; Kato III $(A, B)$, Jurkat $(C, D)$. Image A and C show untreated cells. The arrows show apoptosis cells (magnification, $\times 400)$

Table 2. Screening for antibacterial activity of ethyl acetate crude extracts against human pathogenic bacteria

\begin{tabular}{|c|c|c|c|c|}
\hline \multirow{2}{*}{ Fungal strain } & \multicolumn{4}{|c|}{ Inhibition zone diameter (mm) } \\
\hline & S. aureus & B. cereus & P. aeruginosa & E. coli \\
\hline Xylaria sp.1 & $18.50 \pm 1.50^{b}$ & $12.66 \pm 1.60^{\mathrm{c}}$ & $10.50 \pm 0.86^{c}$ & $9.16 \pm 1.04^{b}$ \\
\hline Xylaria sp.2 & - & $15.16 \pm 0.57^{\mathrm{a}}$ & $8.50 \pm 0.50^{\mathrm{e}}$ & - \\
\hline Xylaria sp.3 & $20.83 \pm 1.04^{\mathrm{a}}$ & $15.50 \pm 0.86^{\mathrm{a}}$ & $11.83 \pm 0.28^{b}$ & $10.66 \pm 0.76^{a}$ \\
\hline Xylaria sp.4 & $18.16 \pm 3.54^{\mathrm{b}}$ & $14.00 \pm 0.50^{\mathrm{b}}$ & $7.83 \pm 1.04^{\mathrm{e}}$ & - \\
\hline Xylaria sp.5 & $8.50 \pm 0.50^{\mathrm{d}}$ & $12.00 \pm 0.86^{\mathrm{c}}$ & - & $9.33 \pm 1.04^{b}$ \\
\hline Xylaria sp.6 & $18.00 \pm 1.32^{b}$ & $7.50 \pm 0.22^{f}$ & $12.66 \pm 0.76^{\mathrm{a}}$ & $9.83 \pm 1.25^{a b}$ \\
\hline Xylaria sp.7 & $8.83 \pm 1.04^{\mathrm{d}}$ & - & $9.50 \pm 0.50^{\mathrm{d}}$ & $7.90 \pm 0.36^{c}$ \\
\hline Xylaria sp.8 & $13.16 \pm 0.76^{\mathrm{c}}$ & $12.66 \pm 1.04^{\mathrm{c}}$ & - & - \\
\hline Daldinia concentrica & $8.16 \pm 0.28^{\mathrm{d}}$ & $9.66 \pm 1.52^{\mathrm{d}}$ & - & $7.33 \pm 0.76^{\mathrm{c}}$ \\
\hline Hypoxylon sp.1 & $7.33 \pm 0.28^{e}$ & $8.16 \pm 1.60^{\mathrm{e}}$ & $7.50 \pm 0.50^{\mathrm{e}}$ & - \\
\hline Hypoxylon sp.2 & $7.50 \pm 0.86^{\mathrm{e}}$ & $12.50 \pm 0.50^{\mathrm{c}}$ & $6.33 \pm 0.28^{\mathrm{f}}$ & - \\
\hline
\end{tabular}

Different small letters indicate significant differences, (-) no clear zone 
Table 3. Anticancer activity of ethyl acetate crude extracts against human cancer cell lines

\begin{tabular}{l|c|c|c|c}
\hline \multirow{2}{*}{ Fungal strain } & \multicolumn{4}{|c}{ Percentage of cell viability } \\
\cline { 2 - 5 } & Kato III & HepG2 & SW620 & Jurket \\
\hline Xylaria sp.1 & $36.87 \pm 1.65^{\mathrm{g}}$ & $45.35 \pm 1.34^{\mathrm{h}}$ & $48.85 \pm 0.91^{\mathrm{e}}$ & $38.62 \pm 0.38^{\mathrm{g}}$ \\
Xylaria sp.2 & $41.03 \pm 1.09^{\mathrm{f}}$ & $51.14 \pm 0.67^{\mathrm{g}}$ & $43.26 \pm 1.47^{\mathrm{g}}$ & $46.55 \pm 1.10^{\mathrm{d}}$ \\
Xylaria sp.3 & $26.12 \pm 0.90^{\mathrm{h}}$ & $42.25 \pm 0.74^{\mathrm{i}}$ & $46.24 \pm 1.12^{\mathrm{f}}$ & $35.37 \pm 0.40^{\mathrm{h}}$ \\
Xylaria sp.4 & $42.66 \pm 1.12^{\mathrm{f}}$ & $58.59 \pm 1.10^{\mathrm{f}}$ & $56.32 \pm 0.47^{\mathrm{c}}$ & $44.00 \pm 1.51^{\mathrm{e}}$ \\
Xylaria sp.5 & $52.15 \pm 0.83^{\mathrm{c}}$ & $63.74 \pm 0.41^{\mathrm{d}}$ & $66.23 \pm 0.71^{\mathrm{a}}$ & $45.20 \pm 0.72^{\mathrm{d}}$ \\
Xylaria sp.6 & $56.67 \pm 0.61^{\mathrm{b}}$ & $66.31 \pm 0.18^{\mathrm{b}}$ & $58.71 \pm 1.08^{\mathrm{b}}$ & $46.39 \pm 1.31^{\mathrm{d}}$ \\
Xylaria sp.7 & $48.92 \pm 0.02^{\mathrm{d}}$ & $66.17 \pm 1.41^{\mathrm{b}}$ & $42.55 \pm 1.06^{\mathrm{h}}$ & $49.23 \pm 0.79^{\mathrm{c}}$ \\
Xylaria sp.8 & $51.36 \pm 0.69^{\mathrm{c}}$ & $62.89 \pm 0.88^{\mathrm{de}}$ & $47.82 \pm 1.00^{\mathrm{ef}}$ & $43.45 \pm 0.94^{\mathrm{e}}$ \\
Daldinia concentrica & $44.42 \pm 1.51^{\mathrm{e}}$ & $65.23 \pm 1.82^{\mathrm{c}}$ & $55.02 \pm 0.93^{\mathrm{d}}$ & $62.26 \pm 0.89^{\mathrm{a}}$ \\
Hypoxylon sp.1 $_{\text {Hypoxylon } \text { sp.2 }}$ & $58.17 \pm 1.27^{\mathrm{a}}$ & $74.18 \pm 0.42^{\mathrm{a}}$ & $67.35 \pm 1.29^{\mathrm{a}}$ & $54.75 \pm 1.06^{\mathrm{b}}$ \\
\hline
\end{tabular}

Different small letters indicate significant differences

\section{Discussion}

Than Mayom exhibited the lowest diversity index. It could be suggested that the difference in rainfall could affect the number and diversity of Xylariaceous fungi. The average rainfall of Klong Plu, Klong Jao Leuam and Kheeri Petch waterfall during sampling period was higher than Than Mayom waterfall (Figure 1). Priyamvada et al. (2017) suggested that the environmental factors such as temperature, humidity and rainfall have directly effect on macro fungi diversity and the ascomycetous fungi have a tendency to appear after a rainfall. However, the appearance rate of the Ascomycota after rainfall is relatively lower when compared to the Basidiomycota.

Ethyl acetate was used for bioactive metabolites extraction because it is easy for evaporation and low toxic (Minarni et al., 2017). The ethyl acetate crude extracts inhibited the growth of Gram positive bacteria greater than that of Gram negative bacteria. These results were in concordance with the results of Canli et al. (2016) who found that the crude extracts of Xylaria hypoxylon has antimicrobial activity against several Gram positive and Gram negative microorganisms. Xylaria hypoxylon samples showed the highest inhibition zone of $16 \mathrm{~mm}$ against S. aureus ATCC 25923. Nikaido (1998) reported that Gram positive bacteria are more susceptible to a larger number of chemotherapeutic agents than Gram negative bacteria. These results may be due to the fact that the cell wall of Gram positive bacteria have a single layer, whereas Gram negative bacteria have multi-layered structure and quite complex (Yao and Moellering, 1995). The crude extract of Xylaria sp.3 showed the highest potential of antibacterial activity and selectively inhibited gastric carcinoma (Kato III) and $\mathrm{T}$ cell leukemia (Jurket). It could be suggested that Xylaria sp. 3 crude extract might represent a promising agent for anticancer activity such as isopimarane, diterpene, glycosides, flavonoids and phenolic compounds. These bioactive compounds were reported to be high potential anticancer agents produced by Xylariaceae (Ramesh et al., 2015; Gouda et al., 2016; Abotaleb et al., 2019). Orachaipunlap et al. (2015) reported that ten selected crude extracts were examined for cytotoxicity against 5 human cancer cell lines [Human colorectal adenocarcinoma (SW620), Human acute T cell leukemia (Jurkat), breast cancer 
(BT474), Human gastric carcinoma (Kato-III), and Human liver hepatoblastoma (HepG2)] and Xylaria TR25 possessed the highest anticancer activity against Kato-III. Furthermore, Xylaria curta collected from tropical evergreen forest in India exhibited significant cytotoxic activity of $58.50 \%$ against human lung cancer cell lines (A-549) (Ramesh et al., 2015). Moreover, truncatones A and C produced by Annulohypoxylon viridistratum (Hypoxylaceae) exhibited high potential against human breast AC (MCF7) (Becker et al., 2020). These results show that different cancer cell lines might exhibit different sensitivities when treated with different extracts. Furthermore, the level of inhibition has been found to be dependent on the fungal strains used and the solvent used for the extraction (Synytsya et al., 2017).

DNA fragmentation as an indication of apoptosis is a commonly used assay in drugcell interaction studies. Cellular physiological and morphological change associated with apoptosis process steps include cell density decreasing, condensation of chromatin and fragmentation of nucleus (Elmore, 2007; Minarni et al., 2017). Bioactive compounds that inhibit the growth of cancer cells by inducing apoptosis may show a useful mechanistic approach to cancer chemotherapy, chemoprevention and preventing unfavorable side effects and resistance (Shafi et al., 2009). It could be developed for cancer treatment in the future. Xylaria sp.TP5BS101 has been reported by Osono et al. (2011), during studies on the decomposition of wood, petiole and leaf litter by Xylaria sp.TP5BS101. However, there was no report on the antibacterial and anticancer activity of this xylariaceous fungus.

\section{Conclusion}

In conclusion, eleven strains in three genera of stromatic Xylariales were isolated from the forest area of the waterfalls in Ko Chang Island. Three genera of Xylariaceae and Hypoxylaceae were found including Xylaria, Daldinia and Hypoxylon. They are a promising repertoire of bioactive metabolites. Xylaria sp. 3 showed the highest potential of antibacterial activity and anticancer activity, and the crude extract exhibited specifically exhibits anticancer activity against Kato III and Jurket cancer cell lines by inducing DNA fragmentation. However, further studies are necessary to investigate the chemical structure of the ethyl acetate crude extracts.

Acknowledgements. The authors gratefully acknowledge climatic data support from the Hydro and Agro Informatics Institute, Department of Microbiology, Faculty of Science, Chulalongkorn University to provide the cancer cell lines for anticancer activity assay. This research receipted financial supported by Government Budget Grant (2560A17402004), Pathumwan Institute of Technology (001/2560) and King Mongkut's Institute of Technology Ladkrabang (Grant Number A118-0361-055 and KREF046105).

\section{REFERENCES}

[1] Abotaleb, M., Samuel, S.M., Varghese, E., Varghese, S., Kubatka, P., Liskova, A., Büsselberg, D. (2019): Flavonoids in cancer and apoptosis. - Cancers 11: 28.

[2] Becker, K., Wessel, A., Luangsa-Ard, J.J., Stadler, M. (2020): Viridistratins A-C, Antimicrobial and cytotoxic benzo[j]fluoranthenes from stromata of Annulohypoxylon viridistratum (Hypoxylaceae, Ascomycota). - Biomolecules 10: 805.

[3] Canli, K., Akata, I., Altuner, E.M. (2016): In vitro antimicrobial activity screening of Xylaria hypoxylon. - African Journal of Traditional, Complementary and Alternative Medicines 13: 42-46. 
[4] Edwards, R.L., Jonglaekha, N., Kshirsagar, A., Maitland, D.J., Mekkamol, S., Nugent, L.K., Phosri, C., Rodtong, S., Ruchichachorn, N., Sangvichien, E., Sharples, G.P., Sihanonth, P., Suwannasai, N., Theinhirun, S., Whalley, A.J.S., Whalley, M.A. (2003): The Xylariaceae as phytopathogens. - Recent Research Development in Plant Science 1: 1-19.

[5] Elias, L.M., Fortkamp, D., Sartori, S.B., Ferreira, M.C., Gomes, L.H., Azevedo, J.L., Montoya, Q.V., Rodrigues, A., Ferreira A.G., Lira, S.P. (2018): The potential of compounds isolated from Xylaria spp. as antifungal agents against anthracnose. -Brazilian Journal of Microbiology 49: 840-847.

[6] Elmore, S. (2007): Apoptosis: A review of programmed cell death. - Toxicologic Pathology 35: 495-516

[7] Fróhlicha, J., Hyde, K.D., Petrini, O. (2000): Endophytic fungi associated with palms. Mycological Research 104: 1202-1212.

[8] Gouda, S., Das, G., Sen, S.K., Shin, S.H., Patra, J.K. (2016): Endophytes: A treasure house of bioactive compounds of medicinal importance. - Frontiers in Microbiology 7: 1538.

[9] Helaly, S.E., Thongbai, B., Stadler, M. (2018): Diversity of biologically active secondary metabolites from endophytic and saprotrophic fungi of the ascomycete order Xylariales. Natural Product Reports 35: 992-1014.

[10] Ju, Y.M., Rogers, J.D. (1996): A revision of the genus Hypoxylon: Mycologia Memoirs no. 20. - APS Press, Saint Paul, Minnesota.

[11] Koyani, R.D., Patel, H.R., Vasava, A.M., Rajput, K.S. (2016): Xylariaceae: Overview and addition to fungal diversity of Gujarat state. - Studies in Fungi 1: 69-79.

[12] Minarni, Artika, I.M., Julistiono, H., Bermawie, N., Riyanti, E.I., Hasim, Hasan, A.E.Z. (2017): Anticancer activity test of ethyl acetate extract of endophytic fungi isolated from soursop leaf (Annona muricata L.). - Asian Pacific Journal of Tropical Medicine 10: 566571.

[13] Nikaido, H. (1988): Antibiotic resistance caused by Gram-negative multidrug efflux pumps. - Clinical Infectious Diseases 27: 32-41.

[14] Orachaipunlap, K., Suwannasai, N., Whalley, A.J.S., Phosri, C., Sihanonth, P. (2016): Biological activities of endophytic Xylaria sp. isolated from tropical forest in Chaiyapoom province, Thailand. - Biological and Chemical Research 3: 200-208.

[15] Orachaipunlap, K., Suwannasai, N., Whalley, A.J.S., Roengsumran, S., Sihanonth, P. (2015): Antibacterial and Anticancer Activity of Stromatic Xylaria spp. from Tropical Forest Thailand. - KMITL Science and Technology Journal 15: 1-9.

[16] Osmanova, N., Schultze, W., Ayoub, N. (2010): Azaphilones: a class of fungal metabolites with diverse biological activities. - Phytochemistry Reviews 9: 315-342.

[17] Osono, T., To-Anun, C., Hagiwara, Y., Hirose, D. (2011): Decomposition of wood, petiole and leaf litter by Xylaria species from northern Thailand. - Fungal Ecology 4: 210-218.

[18] Petrini, L.E., Petrini, O. (1985): Xylariaceous fungi as endophytes. - Sydowia 38: 216-234.

[19] Pharamat, T., Palaga, T., Piapukiew, J., Whalley, A.J.S., Sihanonth, P. (2013): Antimicrobial and anticancer activities of endophytic fungi from Mitrajyna javanica Koord and Val. - African journal of microbiology research 7: 5565-5572.

[20] Priyamvada, H., Akila, M., Singh, R.K., Ravikrishna, R., Verma, R.S., Philip, L., Marathe, R.R., Sahu, L.K., Sudheer, K.P., Gunthe, S.S. (2017): Terrestrial macrofungal diversity from the tropical dry evergreen biome of southern India and its potential role in aerobiology. - PLoS One 12: e0169333.

[21] Pumijumnong, N., Payomrat, P. (2013): The effective ecological factors and vegetation at Koh Chang Island, Trat Province, Thailand. - Open Journal of Forestry 3: 41-48.

[22] Ramesh, V., Santosh, K., Pavunraj, M., Karunakaran, C., Rajendran, A. (2015). In-vitro antifungal and anticancer potential of Xylaria curta fruiting body fractions against human fungal pathogen and cancer cell lines. - Current Research in Environmental and Applied Mycology 5: 20-26. 
[23] Ramesh, V., Thalavaipandian, A., Karunakaran, C., Rajendran, A. (2012): Identification and comparison of Xylaria curta and Xylaria sp. from Western Ghats-Courtallum Hills, India. - Mycosphere 3: 607-615.

[24] Rezk, A., Al-Hashimil, A., John, W., Schepker, H., Ullrich, M.S., Brix, K. (2015): Assessment of cytotoxicity exerted by leaf extracts from plants of the genus Rhododendron towards epidermal keratinocytes and intestine epithelial cells. - BMC Complementary and Alternative Medicine 15: 364

[25] Rodrigues, K.F. (1994): The foliar fungal endophytes of the Amazonian palm Euterpe oleracea. - Mycologia 86: 376-385.

[26] Shafi, G., Munshi, A., Hasan, T.N., Alshatwi, A.A., Jyothy, A., Lei, D.K. (2009): Induction of apoptosis in HeLa cells by chloroform fraction of seed extracts of Nigella sativa. Cancer Cell International 9: 29.

[27] Simpson, E.H. (1949): Measurement of diversity. - Nature 163: 688.

[28] Sutjaritvorakul, T., Chutipaijit, S. (2018). Biogenic synthesis and antibacterial activity of silver nanoparticles (AgNPs) produced by Phomopsis sp. strain GFPA2. - Journal of Metals, Materials and Minerals 28: 41-46.

[29] Sutjaritvorakul, T., Gadd, G.M., Whalley, A.J.S., Suntornvongsagul, K., Sihanonth, P. (2016). Zinc oxalate crystal formation by Aspergillus nomius. - Geomicrobiology Journal 33: 289-293.

[30] Sutjaritvorakul, T., Whalley, A.J.S., Sihanonth, P., Roengsumran, S. (2011): Antimicrobial activity from endophytic fungi isolated from plant leaves in Dipterocarpous forest at Viengsa district Nan province, Thailand. - International Journal of Agricultural Technology 7: 115-121.

[31] Synytsya, A., Monkai, J., Bleha, R., Macurkova, A., Ruml, T., Ahn, J., Chukeatirote, E. (2017): Antimicrobial activity of crude extracts prepared from fungal mycelia. - Asian Pacific Journal of Tropical Biomedicine 7: 257-261.

[32] Thomas, D.C., Vandegrift, R., Ludden, A., Carroll, G.C., Roy, B.A. (2016): Spatial ecology of the fungal genus Xylaria in a tropical cloud forest. - Biotropica 48: 381-393.

[33] Velmurugan, N., Lee, H.M., Han, S.S., Sol, L., Lee, Y.S. (2013): Xylariaceae diversity in Thailand and Philippines, based on rDNA sequencing. - Annals of Forest Science 56: 3142.

[34] Whalley, A.J.S. (1996): The xylariaceous way of life. - Myological Research 100: 879922.

[35] Yao, J., Moellering, R. (1995): Antibacterial Agents. - In: Murray, P., Baron, E., Pfaller, M., Tenover, F., Yolken, R. (Eds.) Manual of Clinical Microbiology. ASM, Washington. 